\title{
Hepatic Histologic Changes in Patients with Chronic Hepatitis B Virus Infection with High DNA Level and Normal or Minimally Elevated Alanine Aminotransferase
}

\author{
ASM Salimullah ${ }^{1}$, ASMA Raihan $^{2}$, MMSU Islam $^{3}$, MA Rahman $^{4}$, DS Ahmed $^{5}$, \\ MR Bhuiyan ${ }^{6}$, MR Khan ${ }^{7}$, M Sharmin ${ }^{8}$, M Rahman ${ }^{9}$
}

\begin{abstract}
:
Hepatitis B Virus (HBV) infection can causes spectrum of diseases ranging from clinically asymptomatic state to the development of cirrhosis and hepatocellular carcinoma (HCC). There is ongoing debate in the management of asymptomatic patients with chronic hepatitis B virus (CHBV) infection with high DNA and normal ALT level. It has been recently shown that a significant proportion of patients with CHBV infection with high DNA and normal ALT level have significant histological abnormality. So this study was aimed to see the histological changes in patients with CHBV infection with high DNA and ALT level $<2$ times of upper limit of normal (ULN). Total 64 patients were included in this cross sectional study. Mean age was 29 years, $55(85.9 \%)$ patients were men. Forty patients (62.5\%) were $\mathrm{HBeAg}$ positive. Thirty seven (57.8\%) patients had normal ALT levels and 27 patients (42.2\%) had ALT levels $1-2$ x ULN. Out of 64 patients $46.8 \%$ had significant histological abnormalities. Among them $31.2 \%$ had significant fibrosis and $26.5 \%$ had significant necroinflammatory changes. Among 37 patients with normal ALT levels $35 \%$ had significant histological abnormalities. But among 27 patients with ALT levels of 1-2 x ULN, 63\% had significant histological abnormalities. In this series significant histological abnormalities were found in $40 \% \mathrm{of} \mathrm{HBe} \mathrm{Ag}+\mathrm{ve}$ cases and $58.3 \%$ of $\mathrm{HBeAg}$-ve cases. But this difference was not statistically significant. It was also found that patients with significant histological abnormalities were significantly older and had a lower median HBV DNA level, lower mean platelet count, lower mean prothrombin activity ratio and lower mean albumin level than patients with nonsignificant histological changes. In logistic regression analysis it was found that serum ALT levels and age at which patients entered the study were independently associated with the risk for significant histological abnormalities.
\end{abstract}

Key words: Chronic Hepatitis B Virus, HBV DNA, ALT, Fobrosis, Necroinflammation.

\section{Introduction:}

Chronic hepatitis B virus (CHBV) infection can cause a spectrum of diseases ranging from clinically

1. Dr. ASM Salimullah, MBBS, FCPS (Medicine), MD (Gastroenterology), Assistant Professor (CC), Department of Gastroenterology, Dhaka Medical College, Dhaka.

2. Dr. A.S.M.A. Raihan, MBBS, MD (Gastroenterology), Professor \& Head, Department of Gastroenterology, Bangabandhu Sheikh Mujib Medical University (BSMMU), Dhaka.

3. Dr. M.M. Shahin-Ul-Islam, MBBS, FCPS (Medicine), MD (Gastroenterology), Assistant Professor, Department of Gastroenterology, Faridpur Medical College, Faridpur.

4. Dr. Mohammad Asadur Rahman, MBBS, MD (Gastroenterology), Medical Officer, Department of Gastroenterology, Bangabandhu Sheikh Mujib Medical University (BSMMU), Dhaka.

5. Dr. Dewan Saifuddin Ahmed, MBBS, FCPS (Medicine), MD (Gastroenterology), Professor, Department of Gastroenterology, Bangabandhu Sheikh Mujib Medical University (BSMMU), Dhaka.

6. Dr. Mujibur Rahman Bhuiyan, MBBS, FCPS (Medicine), MD (Gastroenterology), Senior Consultant, Department of Gastroenterology, Apollo Hospital, Dhaka.

7. Dr. Masudur Rahman Khan, MBBS, MD (Gastroenterology), Associate Professor, Department of Gastroenterology, Bangabandhu Sheikh Mujib Medical University (BSMMU), Dhaka.

8. Dr. Maliha Sharmin, MBBS, FCPS (Opthalmology), Assistant Professor, Lions Eye Institute \& Hospital, Dhaka.

9. Dr. Mahabub Rahman, MBBS, FCPS (Medicine), MD (Gastroenterology), Associate Professor (CC), IBN Sina Medical College, Dhaka.

\section{Address of correspondence :}

Dr. ASM Salimullah, MBBS, FCPS (Medicine), MD Dr. ASM

Salimullah, MBBS, FCPS (Medicine), MD (Gastroenterology),

Assistant Professor (CC), Department of Gastroenterology, Dhaka

Medical College, Dhaka. Phone: +88-01711195331,

Email: drsalimullah@ymail.com asymptomatic state to the development of cirrhosis and hepatocellular carcinoma. Four phase of CHBV infection have been defined. In immune-tolerant phase, patients are asymptomatic, hepatitis e antigen $(\mathrm{HBeAg})$ is positive, serum HBV DNA levels are high, serum alanine aminotransferase (ALT) levels are normal or minimally elevated, and there is possibly minimal histological activity.

An area of ongoing debate in the management of hepatitis $\mathrm{B}$ is the management of asymptomatic patients with $\mathrm{CHBV}$ infection who are $\mathrm{HBeAg}$ positive with normal ALT level, i.e. who are immune-tolerant. The American Association for the Study of Liver Diseases (AASLD) guidelines recommend monitoring of such patients without treatment if ALT levels are less than two times the upper limit of normal ${ }^{1}$. The US algorithm recommends an individualized approach for liver biopsy to CHBV infected patients in the immunotolerant phase and consideration of treatment if significant disease is present ${ }^{2}$.

Asian Pacific Association for the Study of the Liver (APASL) guidelines recommend liver biopsy as an important test in older patients with normal ALT levels in association with high HBV DNA levels, whether they are $\mathrm{HBeAg}$ positive or $\mathrm{HBeAg}$ negative, to determine whether significant histological abnormality 
is present ${ }^{3}$. Many studies have shown low prevalence of significant liver injuries in CHBV patients with normal ALT levels ${ }^{4-8}$. A few studies have reported hepatic injuries in a fair proportion of these patients ${ }^{9-11}$.

It has been assumed that patients in the immunetolerant phase of chronic hepatitis $B$, have relatively little liver damage, a benign course, and do not require therapy $^{12}$. However, it has been recently shown that a significant proportion of patients with immune-tolerant phase have significant hepatic fibrosis and many have significant necroinflammatory changes on biopsy. Nguyen and colleagues ${ }^{13}$ described the prevalence of significant liver disease among patients with chronic hepatitis B from Northern California who had normal serum ALT and $>10^{4}$ copies/mL of HBV DNA in the serum. Significant histopathological changes were found in more than $40 \%$ of patients; among patients with persistently normal liver enzymes, $31 \%$ had significant hepatic histopathology. Older age (starting at 35 years) was the best predictor of abnormal liver histology.

Alam S et al $^{14}$ in Bangladesh evaluated on $499 \mathrm{CHB}$ patients and revealed that $52.7 \%$ patients with $\mathrm{HBeAg}$ positive and $23.1 \%$ of $\mathrm{HBeAg}$ negative patients with normal ALT level had significant histological changes. Another study in Bangladesh by Mahtab et $\mathrm{al}^{15}$ showed that considerable number of patients $(26 \%)$ of incidentally detected $\mathrm{CHB}$ patients had significant histological changes.

There is increasing evidence that a high viral load per se, regardless of ALT levels, may be an important risk factor for progression of end-stage liver disease, such as cirrhosis and $\mathrm{HCC}^{11,12,16}$. Moreover, some patients with persistently normal ALT levels have significant hepatic pathology upon biopsy examination ${ }^{17}$. Early detection of patients with significant histology and the appropriate treatment can prevent the progression of end-stage liver disease. There are, however few studies evaluating histopathologic findings in these group of patients specially in our country. So this study was aimed to reveal the histological findings in chronic hepatitis B (CHB) patients with high viral load and normal or slightly elevated serum ALT levels, who may be potential candidates for antiviral therapy.

\section{Material and Methods:}

This cross sectional study was conducted in Gastroenterology department of Bangabandhu Sheikh Mujib Medical University (BSMMU) in the period from January, 2008 to October, 2009. Patients having HBsAg positivity for at least 6 months, ALT less than $2 \mathrm{x}$ (UNL), HBV DNA levels $>10^{5}$ copies $/ \mathrm{mL}$ in $\mathrm{HBeAg}+\mathrm{ve}$ and $>10^{4}$ copies $/ \mathrm{mL}$ in $\mathrm{HBeAg}$-ve cases were included in this study. Patients having hepatitis $\mathrm{C}$ virus co-infection, liver disease because of other etiology, clinical, sonological and endoscopic evidence of cirrhosis were excluded from this study. Patients who fulfilled the inclusion criteria were enrolled for liver biopsy and admitted in hospital. Total 64 patients were included in this study. With all necessary measure and aseptic precautions liver biopsy was done under local anaesthesia after taking written informed consent. Knodell scoring system was used to grade \& stage necroinflammatory \& fibrotic changes. Significant histopathological abnormality was defined as fibrosis stage $\geq \mathrm{F} 2$ or necroinflammation, HAI $>8$. All statistical analyses were performed with commercially available software (SPSS 11.0) and appropriate test of significance were applied for statistical significance.

\section{Results:}

Table-I shows the characteristics of patients analyzed in this study. Out of 64 patients 55 were men. Mean age was 29 years (range, 14-56 years). HBeAg was positive in 40 patients. Thirty seven patients had normal ALT levels and 27 patients had abnormal ALT levels (1-2 x ULN).

Table I: Clinical Characteristics of Study Population: $n=64$

\begin{tabular}{ll}
\hline Characteristics & Value \\
\hline Age (Years) & $29 \pm 9.3(14-56)$ \\
Male gender, n (\%) & $55(85.9)$ \\
Family History*, n (\%) & $11(17.2)$ \\
BMI (Kg/m²) & $21.6 \pm 3,9(16.7-32.1)$ \\
HBeAg+ve, n (\%) & $40(62.5)$ \\
ALT (IU/L) & $65 \pm 25(27-110)$ \\
Albumin (g/dl) & $38 \pm 4.47(33-49)$ \\
Platelet Count & $2.9 \pm 0.76(1.6-4.1)$ \\
(lac/cmm) & \\
Prothrombin Activity & $86.8 \pm 7.8(74.2-100)$ \\
Ratio (\%) &
\end{tabular}

*Family history of liver-related complications, such as cirrhosis and HCC.

Figure-1 summarizes the histopathological characteristics of study population. Among 37 patients with normal ALT levels, the grading of necroinflammation (NI) showed minimal change in $19 \%$, mild in $68 \%$ and moderate in $13 \%$ patients. The staging of fibrosis showed F0 in $11 \%, \mathrm{~F} 1$ in $59 \%, \mathrm{~F} 2$ in $30 \%$ and overall significant histological changes were found in $35 \%$ patients (Figure: 1 a-1, b-1, c-1). But among 27 patients with ALT levels of 1-2 x ULN, the grading of (NI) showed minimal in $26 \%$, mild in $30 \%$, 
moderate in $44 \%$, and the staging of fibrosis showed F0 in $11 \%, \mathrm{~F} 1$ in $56 \%, \mathrm{~F} 2$ in $33 \%$ and overall significant histological changes were found in $63 \%$ patients). (Figure1: a-2, b-2, c-2).
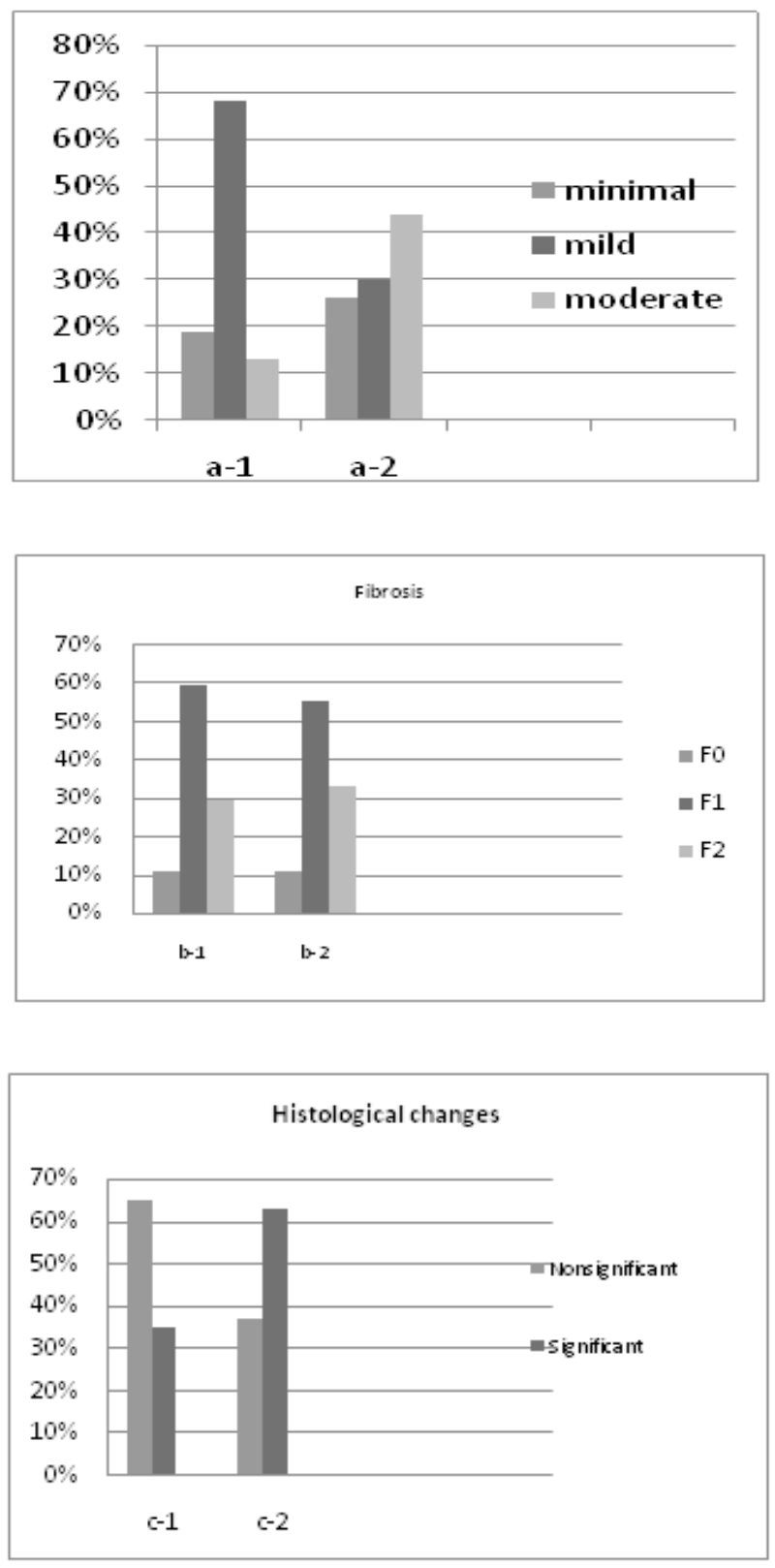

Figure. 1: Histopathological features of the study population. a-1, b-1,c-1 patients with normal ALT. a-2, b-2, c-2 patients with elevated ALT levels of 1-2 x ULN.

Relationship between Pattern of Serum ALT changes and significant histological changes were described in Table-II. Among 37 patients with normal ALT levels, $13(35 \%)$ had significant histological changes whereas $17(63 \%)$ of the 27 patients with ALT levels of 1-2 x ULN had significant histological changes.
Table II: Relationship between pattern of serum ALT changes and significant histological changes

\begin{tabular}{lc}
\hline ALT levels & Patients with significant histology \\
\hline Normal ALT & $13(35 \%)$ \\
levels $(n=37)$ & \\
ALT levels 1-2 & $17(63 \%)$ \\
ULN $(n=27)$ & \\
Total $(n=64)$ & $30(46.8 \%)$ \\
\hline
\end{tabular}

In Table-III, the baseline characteristics between the $\mathrm{HBeAg}+\mathrm{ve}$ and $\mathrm{HBeAg}$-ve groups were compared. The HBeAg-ve group was relatively older (mean age $31.2 \pm 9.1)$ and had a lower mean HBV DNA level (2.6 x $10^{6}$ (copies $/ \mathrm{mL}$ ) as compared with the $\mathrm{HBeAg}+\mathrm{ve}$ group (mean age 27.8 \pm 9.2 , Viral load, $7.9 \times 10^{7}$ copies $/ \mathrm{mL})$. Moderate hepatitis were found in $(22.5 \%)$ in $\mathrm{HBeAg}+\mathrm{ve}$ and $(33.3 \%)$ in $\mathrm{HBeAg}-\mathrm{ve}$ cases. Significant fibrosis were found in $(22.5 \%)$ and $(45.8 \%)$ respectively.

Table III: Difference in baseline characteristics between $\mathrm{HBeAg}+\mathrm{ve}$ and $\mathrm{HBeAg}$-ve cases:

\begin{tabular}{|c|c|c|c|}
\hline Characteristics & $\begin{array}{l}\text { HBeAg+ve } \\
(n=40)\end{array}$ & $\begin{array}{l}\text { HBeAg- } \\
\text { ve( }(n=24)\end{array}$ & $P$-value \\
\hline Age (years) & $27.8 \pm 9.2$ & $31.2 \pm 9.1$ & 0.16 \\
\hline Male n (\%) & $32(80)$ & $23(95.8)$ & 0.07 \\
\hline $\begin{array}{l}\text { Family history*, n } \\
(\%)\end{array}$ & $6(15)$ & $5(20.8)$ & 0.73 \\
\hline $\mathrm{BMI}\left(\mathrm{kg} / \mathrm{m}^{2}\right)$ & $22.3 \pm 4.4$ & $20.4 \pm 2.6$ & 0.06 \\
\hline $\begin{array}{l}\text { Viral load (copies/ml, } \\
\text { mean) }\end{array}$ & $7.9 \times 10^{7}$ & $2.6 \times 10^{6}$ & 0.05 \\
\hline ALT (IU/L) & $62.1 \pm 26$ & $69.9 \pm 22.5$ & 0.21 \\
\hline Albumin (g/dl) & $39.1 \pm 4.5$ & $37.7 \pm 4.2$ & 0.20 \\
\hline $\begin{array}{l}\text { Platelet count } \\
\text { (lac/cu.mm) }\end{array}$ & $3 \pm .74$ & $2.7 \pm .77$ & 0.14 \\
\hline $\begin{array}{l}\text { Prothrombin activity } \\
\text { ratio (\%) }\end{array}$ & $86.1 \pm 7.7$ & $85.3 \pm 8.2$ & 0.70 \\
\hline $\begin{array}{l}\text { Moderate hepatitis } n \\
\text { (\%) }\end{array}$ & $9(22.5)$ & $8(33.3)$ & 0.70 \\
\hline $\begin{array}{l}\text { Significant fibrosis n } \\
\text { (\%) }\end{array}$ & $9(22.5)$ & $11(45.8)$ & 0.08 \\
\hline $\begin{array}{l}\text { Significant histology, } \\
\mathrm{n}(\%)\end{array}$ & $16(40)$ & $14(58.3)$ & 0.19 \\
\hline
\end{tabular}

*Family history of liver-related complications, such as cirrhosis and HCC. 
In Table-IV the baseline characteristics between the significant and non-significant histology groups were compared. The patients with significant histological abnormality was significantly older and had a lower median HBV DNA level, as compared with patients with non-significant histological abnormality (all $\mathrm{P}<0.001)$. The significant histology group had a lower mean platelet count and lower mean prothrombin activity ratio and lower mean albumin level than the non-significant histology group.

\begin{tabular}{llll} 
Table IV: & \multicolumn{2}{l}{ Difference in baseline characteristics } \\
between patients with significant histological \\
abnormality and patients with non-significant \\
histology.
\end{tabular}

*Family history of liver-related complications, such as cirrhosis and HCC.

In logistic regression analysis, serum ALT levels and age at which patients entered the study were independently associated with the risk for significant histology (Table-V). The odds ratios for significant histology increased progressively according to serum ALT levels and age. Compared with patients aged $\leq 30$ years, the odds ratio for significant histology was $3.6(95 \% \mathrm{CI}, 1.07-12.17)$ for patients aged 30-39 years; and 8.6 (95\% CI, 1.6-46.9), for those $\geq 40$ years. Compared with the lowest ALT levels $(\leq 0.5 \times$ ULN), ALT levels of $0.5-1,1-1.5$ and 1.5-2 x ULN were associated with odds ratios $(95 \% \mathrm{CI})$ for significant histology of 6.4 (0.7-58.9), 9(.9-88.9) and 21.3 (1.81252.1 ), respectively.
Table V: Predictors of Significant Histology in CHB Patients with High Viral Load and Normal or Slightly Elevated Serum ALT Levels

\begin{tabular}{|c|c|c|c|}
\hline Predictors & $\mathrm{n} / \mathrm{N}^{*}(\%)$ & Odds ratio $(95 \% \mathrm{Cl})$ & P-value \\
\hline Age (years) & & & $<0.001$ \\
\hline$<30$ & $12 / 38(31.5)$ & 1 (reference) & \\
\hline $30-39$ & $10 / 16(62.5)$ & $3.6(1.07-12.17)$ & \\
\hline$\geq 40$ & $8 / 10(80)$ & $8.6(1.6-46.9)$ & \\
\hline ALT level & & & 0.019 \\
\hline$<0.5 \times$ ULN & $1 / 9(11.1)$ & 1 (reference) & \\
\hline $0.5-1 \times$ ULN & $12 / 27(44.4)$ & $6.4(0.7-58.9)$ & \\
\hline $1-1.5 \times$ ULN & 9/17 (52.9) & $9(.9-88.9)$ & \\
\hline $1.5-2 \times$ ULN & 8/11 (72.7) & $21.3(1.81-252.1)$ & \\
\hline
\end{tabular}

*Number of patients with significant histology/total number of subject.

\section{Discussion:}

Chronic HBV infection is a highly heterogeneous disease and the levels of virus replication, activity of liver disease and host immune response can differ considerably among patients ${ }^{7,18,19}$. The variability in the natural history of $\mathrm{HBV}$ infection may be related to differences in clinical status, age, gender, geographic region and host immunity.

The most important finding of this study was that a large proportion of $\mathrm{CHB}$ patients with high viral load and normal or slightly elevated serum ALT levels $(\leq 2 \mathrm{x}$ ULN) had significant NI and fibrosis. Significant histological abnormalities were observed in 30 patients $(46.8 \%)$. These rates are almost similar to those in other reports based on liver biopsy and significant histological evidence ${ }^{10,14,20-22}$. But lower than those reported by JY Park et $\mathrm{al}^{23}$. However, this study was limited by predominantly retrospective and crosssectional designs. JY Park et al. prospectively assessed the histological findings in a homogeneous group of CHB patients with high serum HBV DNA levels and ALT levels $\leq 2 \times$ ULN for at least 12 months.

In this study, HBeAg-ve patients were older and had lower mean viral load than HBeAg+ve patients which is consistent with many studies like Shao et al, in china $^{24}$, Michelle Lai et al in and Mahtab et al ${ }^{15}$ But there was no statistically significant difference in significant histological changes between two groups. In this study, two factors were independently associated with significant liver disease. One was 
patient's age, another was level of ALT. An increased rate of significant histology in CHB patients with high viral load has been linked to increased age. Patients with ALT levels greater than the ULN, showed a statistically significant increase in the risk for significant histological changes.

Most Asian patients generally acquire HBV infection perinatally or during early childhood. In these patients, age can be considered as a surrogate marker for disease duration. Patients may continue to experience fluctuating levels of viral replication with recurrent disease flares and remission, which are believed to contribute over time to the progression of liver disease $^{26-28}$. Previous studies have reported that age $\geq 45$ years is an independent predictor of significant histology ${ }^{20,21}$.

In this study, 8 ( $80 \%)$ of 10 patients aged $\geq 40$ years had significant histological changes in liver biopsy specimens. However, among 43 patients aged $\leq 30$ years, significant fibrosis was observed in $9(23.6 \%)$ and significant histology (HAI $>9$ or F3-F4) was found in $12(27.9 \%)$. Age exerts an influence on the probability of significant liver disease. JY Park; YN Park et $\mathrm{al}^{23}$ found that $42(85.7 \%)$ of 49 patients aged $\geq 40$ years had significant histological changes in liver biopsy specimens. This is almost similar to our study, but, among 42 patients aged $\leq 30$ years, significant fibrosis was observed in $14(33.3 \%)$ and significant histology (A2-A3 or F2-F4) was found in $18(42.9 \%)$ that is a bit higher than this study.

Serum ALT level is a biochemical marker reflecting liver damage and is important in the decision to initiate treatment of CHB. The published guidelines suggest an arbitrary ALT level of $>2 \times$ ULN as a definite indication for the treatment of $\mathrm{CHB}^{18,19,29}$. But in patients with ALT levels $<2 \times$ ULN, the presence of mild disease cannot be ascertained. Yuen et al. have shown that the risk for complications increases as the ALT level at presentation increases from $>0.5$ to $2 \mathrm{x}$ $\mathrm{ULN}^{16}$. Moreover, a previous study has demonstrated that even in the presence of normal ALT levels, $20 \%$ of patients with CHB infection had piecemeal necrosis and $10 \%$ had severe hepatic fibrosis or cirrhosis ${ }^{30}$. There is increasing evidence that serum ALT level may not accurately reflect histological status ${ }^{10,20-22,31,32}$. In addition, as patients develop advanced fibrosis, serum ALT levels tend to decrease ${ }^{33}$.

In this study, for patients with ALT levels greater than the ULN, a statistically significant increase in risk for significant histological changes was observed. Furthermore, we found that patients with normal ALT levels had a low degree of pathological findings when compared with patients with ALT levels of 1-2 x ULN. These findings were also supported by study report conducted by JY Park; YN Park et $\mathrm{al}^{23}$. Although patients with ALT levels of 1-2 x ULN had not previously been considered as obvious candidates for antiviral therapy, it has become increasingly apparent that histologically significant liver disease can still occur.

There were several limitations during the interpretation of our findings. First, this was a retrospective observational study with a relatively small number of patients. Second, the majority of our patients were HBeAg-positive. Third, our analyses of ALT levels were based on measurements taken at the time of liver biopsy. Although serum ALT levels can fluctuate spontaneously with time and single value is unlikely to be representative, this limitation could have been partly overcome by follow up for at least 12 months prior to biopsy. Despite these limitations, this study provides some information about histological findings in CHB patients with high viral load and normal or slightly elevated serum ALT levels, who may be potential candidates for antiviral therapy.

\section{Conclusion:}

In conclusion, a large proportion of CHB patients with high viral load and ALT $\leq 2 \times$ ULN had significant liver disease on liver biopsy and should be considered for antiviral therapy. The risk for significant histology increases significantly with age and elevated serum ALT levels. These findings may be important in considering appropriate selection criteria for antiviral therapy. Further prospective studies including a larger number of patients would be needed for validated inference. 


\section{References :}

1. LOK ASF, McMahon BJ. Chronic hepatitis B. Hepatology 2007; 45:507-39.

2. Keefe EB, Dieterich DT, Han SH. A treatment algorithm for the management of chronic hepatitis B virus infection in the United States: an update.Clin Gastroenterol Hepatol 2006;4:936-62.

3. Liaw YF, Leung N, Guan R. Asian-Pacific consensus statement on the management of chronic hepatitis B:a 2005 update.Liver Int 2005; 25: 472-89.

4. Ricci G, De Beac C, Caramia F. Carriers of hepatitis B antigen: an epidemiologic and histologic study. J Infect Dis 1973; 128: 125-28.

5. Tapp E, Jones DM, Hollanders D. Serial Liver biopsies in blood donors with persistent HBs antigenaemia. J Clin Pathol 1976; 29 884-86.

6. Dragosics B, Ferenci P, Hitchman E. Long-term follow-up study of asymptomatic HBsAG-positive voluntary blood donors in Austria:a clinical and histologic evaluation of 242 cases. Hepatology 1987;7:302-06.

7. De Franchis R, DArminio A, Vacchi M. Chronic asymptomatic HBsAg carriers:histologic abnormalities and diagnostic and prognostic value of serologic markersof the prognostic value of serologic
HBV.Gastroenterology 1980;79:521-27.

8. Chandra R, Kapoor D, Agarwal SR. High frequency of biochemical and histological disease in incidentally discovered asymptomatic HBsAg positive carrier:need to change terminology. Hepatology 1999; 30(Suppl 2): A1923.

9. Wang C, Deubner H, Shuhart M. High prevalence of significant fibrosis in patients with immune-tolerance to chronic hepatitis $\mathrm{B}$ infection (abstr). Hepatology 2005;42(Suppl 1):A573.

10. Nguyen MH, Trinh H, Garcia RT. Significant histologic disease in HBV-infected patients with normal to minimally elevated ALT levels at initial evaluation (abstr 1008).Hepatology 2005; 42 (Suppl 1):A593.

11. Iloeje UH, Yang HI, Su J, Jen CL, You SL, Chen CJ. Risk Evaluation of Viral Load Elevation and Associated Liver Disease/Cancer-In HBV (the REVEAL-HBV) Study Group. Predicting cirrhosis risk based on the level of circulating hepatitis B viral load. Gastroenterology. 2006; 130: 678-86.

12. Chen CJ, Yang HI, Su J. REVEAL-HBV Study Group. Risk of hepatocellular carcinoma across a biological gradient of serum hepatitis B virus DNA level. JAMA. 2006; 295: 65-73.

13. Nguyen MH, Trinh HN, Garcia RT, Phan J, Nguyen GH, Weiss G. Highprevalence of significant histologic disease in patients with chronic hepatitis B (CHB) and normal ALT. Hepatology. 2007; 46 680A. [\#993]

14. Alam S, Ahmed N, Mustafa G, Shrestha A, Alam AK, Khan M. Evaluation of normal or minimally elevated alanine aminotransferase,age and DNA level in predicting liver histological changes in chronic hepatitis B.Liver Int. 2011 jul; 31(6):824-30.

15. Al-MahtabM, RahmanS, Akbar SM, Kamal M. Clinical use of liver biopsy for the diagnosis and management of inactive and asymptomatic hepatitis B virus carriers in Bangladesh. J Med Virol.2010;82(8):1350-4

16. Yuen MF, Yuan HJ, Wong DK. Prognostic determinants for chronic hepatitis B in Asians: therapeutic implications. Gut 2005; $54: 1610-14$

17. Yang LM, Xu KC, Zhao YL. Clinical significance of liver biopsy in chronic hepatitis $B$ patients with persistently normal transaminase. Chin J Dig 2002; 3: 150-153.

18. EASL Jury. EASL international consensus conference on hepatitis B. 13-14 September, 2002: Geneva Switzerland, Consensus statement (long version). J Hepatol 2003; 38: 533-40.
19. Liaw YF, Leung NW, Guan R. Asian-Pacific consensus statement on the management of chronic hepatitis B: a 2005 update. Liver Int $2005 ; 25: 533-40$

20. Lai M, Hyatt B, Afdhal N. Role of liver biopsy in patients with normal ALT and high HBV DNA. Hepatology 2005; 42: 720A.

21. Terrault N, Kim R, Schalm S. Presence of biopsy-proven histologic damage (necroinflammation and fibrosis) is common even when ALT is less than 2x ULN in patients with chronic hepatitis B [abstract]. J Hepatol 2007; 46: 483A.

22. Yu MW, Hsu FC, Sheen IS. Prospective study of hepatocellular carcinoma and liver cirrhosis in asymptomatic chronic hepatitis virus carriers. Am J Epidemiol 1997; 145: 1039-47.

23. JY Park, YN Park, DY Kim, YH Paik, KS Lee, Moon BS, et al. High Prevalence of Significant Histology in Asymptomatic Chronic Hepatitis B. J Viral Hepat. 2008;15(8):615-62.

24. Shao J, Wei L, Wang H, et al. Relationship between hepatitis B virus DNA levels \& liver histology in patients with chronic hepatitis B. World journal of gastroenterology 2007;13(14): 2104-07.

25. Lai M, Hyatt BJ, Nasser I, Curry M, Afdhal NH. The clinical significance of persistently normal ALT in chronic hepatitis B infection. Hepatology. 2007; 46: 650A.

26. Chu CM, Hung SJ, Lin J, Tai DI, Liaw YF. Natural history of hepatitis B e antigen to antibody sero-conversion in patients with normal serum aminotransferase levels. Am. J. Med. 2004; 116: 829-34.

27. Realdi G, Fattovich G, Hadziyannis S. Survival and prognostic factors in 366 patients with compensated cirrhosis type B: a multicenter study. The Investigators of the European Concerted Action on Viral Hepatitis (EUROHEP). J Hepatol 1994; 21: 656-66.

28. Ter Borg F, ten Kate FJ, Cuypers HT. A survey of liver pathology in needle biopsies fromHBsAg and anti-HBe positive individuals. J Clin Pathol 2000; 53: 541-48.

29. Park BK, Park YN, Ahn SH. Long-term outcome of chronic hepatitis B based on histological grade and stage. J Gastroenterol Hepatol 2007;22:383-8.

30. Prati D, Taioli E, Zanella A. Updated definitions of healthy ranges for serum alanine aminotransferase levels. Ann InternMed $2002 ; 137: 1-10$.

31. Lin DY, Sheen IS, Chiu CT, Lin SM, Kuo YC, Liaw YF. Ultrasonographic changes of early liver cirrhosis in chronic hepatitis B: a longitudinal study. J Clin Ultrasound 1993; 21: 303-8.

32. Williams AL, Hoofnagle JH. Ratio of serum aspartate to alanine aminotransferase in chronic hepatitis Relationship to cirrhosis. Gastroenterology 1988; 95: 734-39.

33. Liaw YF, Sung JJ, Chow WC. Lamivudine for patients with chronic hepatitis $\mathrm{B}$ and advanced liver disease. $\mathrm{N}$ Engl J Med 2004;351: 1521-53. 